\title{
THE INFLUENCE OF BRAND AWARENESS, BRAND ASSOCIATION, AND PERCEIVED QUALITY TOWARD CONSUMERS' PURCHASE INTENTION: A CASE OF RICHEESE FACTORY, JAKARTA
}

Etty Susilowati Budi Luhur University, Indonesia E-mail: ettysslwt@gmail.com

Agatha Novita Sari Budi Luhur University, Indonesia E-mail: agathanovitas@gmail.com

Submission: $1 / 21 / 2019$

Revision: 2/27/2019

Accept: 3/28/2019

\section{ABSTRACT}

This study investigates the relationship between brand awareness, brand association, perceived quality, brand loyalty and brand purchasing intention. A total of 99 students from Budi Luhur University was used as respondents in this study based on the convenience sampling method. Data were analyzed using Partial Least Square Structural Equation Modeling (PLS-SEM) and SmartPLS 3.0 software. The analysis specifies that there is a significant positive relationship among brand awareness, brand association and perceived quality towards brand loyalty and brand purchasing intention. However, there is not a significant relationship between brand loyalty and brand purchasing intention. It indicates that consumers who are satisfied with Richeese Factory products and services do not always end up making purchases. The ability of managers to understand the factors which shape consumer brand behavior is required to develop and to maintain their brand position in high competitive fast food brand competition.

Keywords: fast food restaurant, brand awareness, brand association, perceived quality, brand loyalty, brand purchasing intention. 
ISSN: 2236-269X

DOI: 10.14807/ijmp.v11i1.981

\section{INTRODUCTION}

Globalization has brought the emergence of many fast food restaurants in Indonesia. The large population and the consumption trend of urban society for easiness and efficiency have created a higher demand for fast food (TANTIA, 2017). Moreover, high population of young people, a large number of women who work on tight schedules and increased income of middle-income class groups have become key antecedents of demand for fast food brands (SINGH; PATTANAYAK, 2016).

The high demand has been responded by the emergence of a many local fast food brands in Indonesia. The local fast food brands often offer a variety of products. However, the products and services provided are relatively similar in the form of the way products are processed, served, packed and the price ranges offered to the consumers. In addition, the brands usually provide delivery services, free wifi, and put special attention to restaurant layouts and interiors.

This has brought a tight competition to the industry. Consumers can easily switch to other brands if there is no special uniqueness and differentiation that distinguishes a brand from its competitors. The uniqueness of products and restaurants has been used as a brand positioning strategy over the past few years in the food service industry (ROBINSON; CLIFFORS, 2012). The uniqueness can be developed in terms of the variety of product, the restaurant's layout, the convenience provided for consumers in the restaurant, and consumer interaction with staffs (TSAI; LU, 2012).

This concept of uniqueness is often challenging for fast food brands that basically have their own concept of serving food quickly and expect consumers to enjoy their food quickly in restaurants as well. High uniqueness of a product will bring high identity, consumer brand awareness and the brand association (LU; GURSOY; LU, 2015).

Elements such as variety and inseparableness will form strong brand equity that highly influences consumer loyalty to products and brands, Increase Company profits, and builds effective marketing strategies (SUN; GHISELLI, 2010). In addition, the existence of global fast food brands that have dominated the fast food market for years in Indonesia, has been creating a high challenge for local fast food restaurants to gain market share. Usually, local food brands are not successful in forming their brand equity as expected (TAN; DEVINAGA; HISHAMUDDIN, 2013).

Although there are growing literatures that discuss the relationship between brand equity and brand purchasing intention in the food service industry (JALILVAND et al., 2016; 
DOI: 10.14807/ijmp.v11i1.981

MAJID et al. 2016; PHUNG; LY; NGUYEN, 2019) and global fast food brands (KASHIFet al., 2015; HANAYSHA, 2016; HARRINGTON; OTTENBACHER; FAUSER, 2017), however there is still a gap in local fast food industries with relatively similar product and service characteristics to the global and other local fast food brands.

Therefore, building brand equity will become more challenging for such restaurants compared to other restaurants which are relatively easier to carry the concept of ethnicity and authenticity. Therefore, in this study, we examine the relationship between brand equity (brand awareness, brand association, perceived quality, and brand loyalty) and brand purchasing intention at a local fast food brand in Jakarta, Indonesia.

This study will contribute to literatures by providing the insight of brand equity relationships with brand purchasing intention, especially in local fast food brands. As the local fast food brand equity is not as successful as the global fast food brands (TAN; DEVINAGA; HISHAMUDDIN, 2013), this study becomes an important source for the businesses to achieve competitive advantage. Furthermore, the managerial implications are provided.

\section{LITERATURE REVIEW}

\subsection{Brand awareness}

Brand awareness is a component of brand equity (FOROUDI et al., 2018). Brand awareness is an ability of consumers to be aware of the existence of a brand (SPRY; PAPPU; BETTINA CORNWELL, 2011). The higher the brand awareness, the higher the consumer's perception of the brand (AAKER, 2009).

Although brand awareness is the first stage of brand equity, but according to Foroudi, et al. (2018), consumers will tend to buy brands that they already recognize. According to Keller (2008), brand awareness consists of two components, namely brand recall and brand recognition. Brand recall is the ability of consumers to remember a certain brand, while brand recognition is the ability of consumers to distinguish certain brands with other brands (HOMBURG; KLARMANN; SCHMITT, 2010).

Moreover, MacInnis, Shapiro, and Mani (1999) used imagery as an indicator to measure brand awareness. Prior studies have indicated a positive relationship among brand awareness with brand loyalty and brand purchasing intention (FOROUDI, et al., 2018; KIM;CHOE; PETRICK, 2018; COELHO; RITA; SANTOS, 2018). Based on the above explanation, the research hypotheses to be tested are: 
DOI: 10.14807/ijmp.v11i1.981

- H1a: Brand awareness has a positive effect on brand loyalty.

- H1b: Brand awareness has a positive effect on brand purchasing intention.

\subsection{Brand association}

The next key component of brand equity is brand association (Foroudi et al., 2018). Brand association is any aspects that consumers can bear in mind from brands in terms of nonphysical characteristics of the product, uniqueness, product innovation, market position and reputation (CHENG-HSUI CHEN, 2001; MOHD YASIN; NASSER NOOR; MOHAMAD, 2007).

Foroudi, Jin, Gupta, Foroudi, and Kitchen (2018) stated that a high brand association will lead to brand fondness. Companies have used brand associations to influence consumers' feelings and attitudes towards products and help them to make purchasing decisions (Aaker, 2009).

Consumer perception of a brand is a multidimensional concept that is influenced by various indicators (KELLER; AAKER, 1997). This study uses indicators of perceived quality (LOW; LAMB JR., 2000), brand personality (AAKER, 1997), and organizational associations (AAKER, 2012) to measure brand associations. Since perceived quality is a more specific concept that determines the perceived value of consumers, therefore in this study, we adopted indicators of perceived value in measuring brand association. Brand personality is a human characteristic related to a brand (KELLER; PARAMESWARAN; JACOB, 2011).

Organizational associations are favorable relationships between consumers and companies. This is according to the assumption that a positive relationship will give the expected impact on consumer attitudes and behavior towards the brand. This is considered more effective than depend on the prominence of single product (AAKER, 2012). Romaniuk and Nenycz-Thiel (2013), Severi and Ling (2013), Maderer, Holtbruegge, and Woodland (2016), Foroudi, Jin, Gupta, Foroudi, and Kitchen (2018) proved a positive relationship between brand association and brand loyalty.

The higher the brand association will lead to the higher consumer's fondness and attachment to the brand. In addition, Foroudi, Jin, Gupta, Foroudi, and Kitchen (2018) represented a positive relationship between the variable and brand purchasing intention. Based on the above explanation, the research hypotheses to be tested are:

- H2a: Brand association has a positive effect on brand loyalty. 
DOI: 10.14807/ijmp.v11i1.981

- H2b: Brand association has a positive effect on brand purchasing intention.

\subsection{Perceived quality}

Perceived quality is the consumer's assessment of superior product or service performances compared with other similar products (ZEITHAML, 1998; SNOJ et al., 2004). The term perceived quality is often exchanged with perceived value. Both indicate consumer evaluations of goods or services. However, basically both have different scope. Perceived value has a broader definition, including consumers' assessment of the overall product and service performance based on their experiences (ZEITHAML, 1998).

Grewal, Krishnan, Baker, and Borin (1998) revealed that perceived quality is the main indicator that determines perceived value. Prior studies have proven that the perceived quality has a positive relationship with brand loyalty (BAKER; CROMPTON, 2000) and brand purchasing intention (GREWAL; MONROE; KRISHNAN, 1998; BAO; BAO; SHENG, 2011; CALVO-PORRAL; LÉVY-MANGIN, 2017; FOROUDI et al., 2018).

Moreover, Bao, Bao, and Sheng (2011) stated that this variable has the most relevant effect on brand purchase intention. The attributes used to measure perceived quality are diverse, including performance, reliability, features, conformance, and durability, serviceability, aesthetics (Garvin, 1984). Moreover, Zethaml (1988) revealed that performance is the main indicator of perceived quality.

Parasuraman, Zethaml, and Berry (1985) stated that there are five common dimensions of service companies, including tangible, reliability, empathy, assurance, and responsiveness. In addition, Brucks and Zeithaml (1987) revealed seven dimensions, namely performance, durability, serviceability, prestige, ease of use, and functionality. Previous empirical studies have revealed there was no standard and general agreement regarding what dimensions should be performed to measure perceived quality. Every industry or type of product and service employs a variety of different dimensions.

This study employs three dimensions of Garvin (1984), namely performance, serviceability, and reliability. Performance is used to measure the characteristics of the product provided. Serviceability measures a company's ability to provide services, and reliability measures the product reliability. Based on the above explanation, the research hypotheses to be tested are:

- H3a: Perceived quality has a positive effect on brand loyalty. 
INDEPENDENT JOURNAL OF MANAGEMENT \& PRODUCTION (IJM\&P)

http://www.ijmp.jor.br

v. 11, n. 1, January-February 2020

ISSN: 2236-269X

DOI: 10.14807/ijmp.v11i1.981

H3b: Perceived quality has a positive effect on brand purchasing intention.

\subsection{Brand loyalty and purchase intention}

Brand loyalty is the consumer's attachment to the brand as represented by the attitude and behavior (ZHANG; VAN DOORN; LEEFLANG, 2014). Attitude indicates the level of customer satisfaction with a brand, while behavior is a consumer's decision to create a purchase of the brand. Fournier and Yao (1997) and Han et. al. (2018) revealed that brand loyalty is an important strategy that should be executed by companies in fierce business competition. Brand loyalty will lead to product purchases (TU; WANG; CHANG, 2012; HAN et. al., 2018).

There are six indicators of brand loyalty as suggesting by Aaker (2009) which cover repurchase intention, satisfaction, preference, premium price, the cost of switching to another brand and commitment to the brand. Brand purchase intention is the expected result of a brand perception (Foroudi, Jin, Gupta, Foroudi, and Kitchen, 2018). Based on the above explanation, the research hypothesis to be tested is:

- H4: Brand loyalty has a positive effect on brand purchasing intention.

The relationship between the variables is denoted in the figure 1 below.

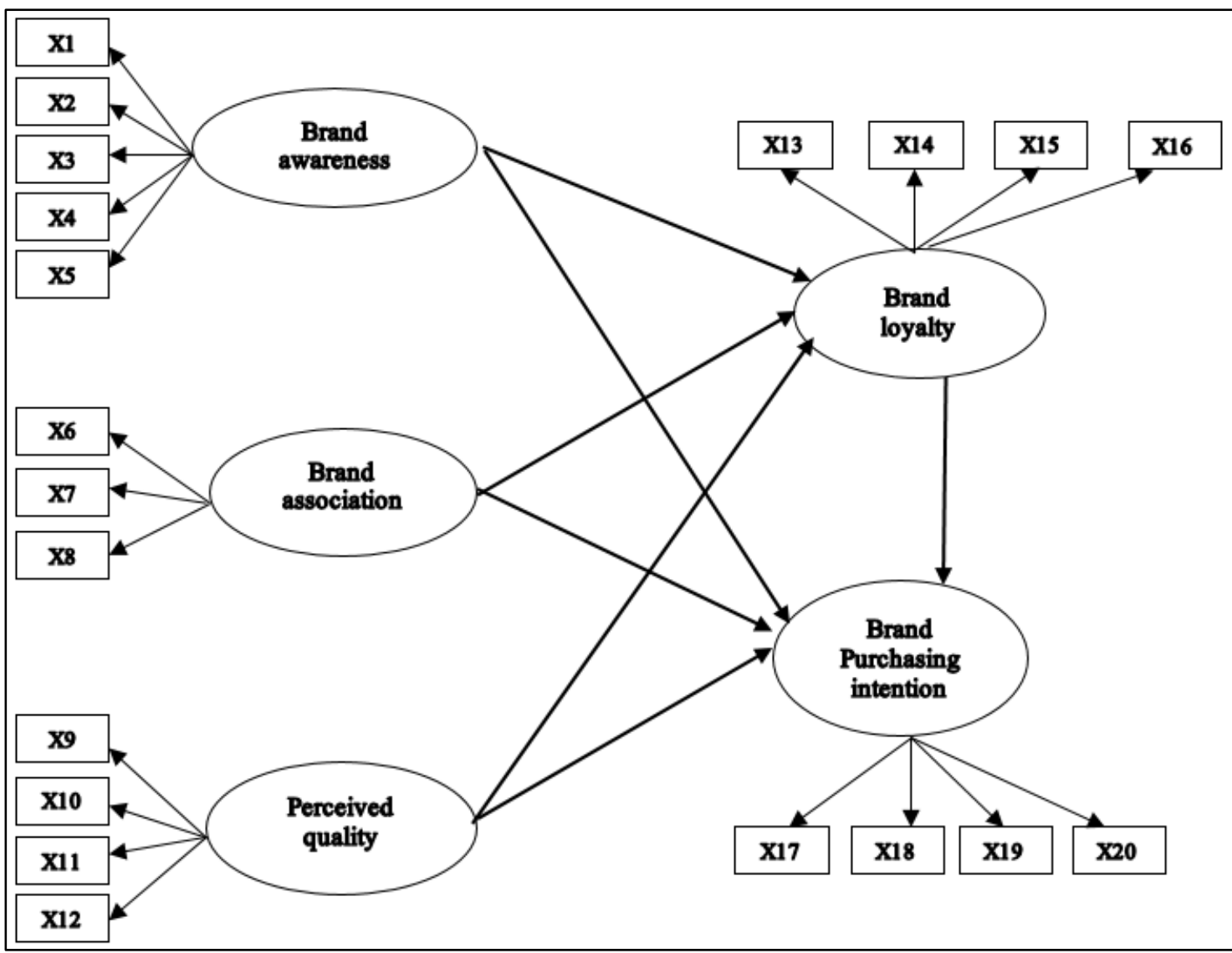


Figure 1: The proposed model

\section{METHOD}

\subsection{Sample and data collection}

The selected local fast food brand in this study is the Richeese Factory. Data indicated that this restaurant already has 59 outlets across Indonesia that outspread to 22 cities in 2018. Despite it was first launched in 2011, the restaurant has a rapid growth due to its franchise concept and high consumer demand for the typical restaurant products (RACHMAWATI, 2018).

The difference with other fast food brands is all the menus served accompanied by a cheese sauce while other fast food restaurants usually use tomato or chili sauce. In this study, specifically, we selected the Richeese Factory, which is located in South Jakarta. The main reason is because the location is near to Budi Luhur University, where we collected our respondents.

The Richeese Factory has assigned high school and university students as their main target market. A total of 99 students from Budi Luhur University was collected as samples in this study. Electronic questionnaires were distributed based on convenience sampling method and Likert Scale. Of the 99 respondents, $51.5 \%$ were male and $48.5 \%$ were female, $97 \%$ were aged 17 to 25 years and only $3 \%$ were aged between 26 to 30 years.

\subsection{Data instruments}

The instrument employed in this study is confirming to the scales used in prior studies. Brand awareness was adopted by following dimensions of MacInnis, Shapiro and Mani (1999), Keller (2008) and empirical applications by Boo, Busser, and Baloglu (2009), Buil, Martínez, and De Chernatony, (2013), while dimensions of brand associations by following Aaker (1997), Low and Lamb Jr. (2000), and Aaker (2012), brand loyalty, and brand purchasing intention by following Foroudi, Jin, Gupta, Foroudi, and Kitchen (2018).

Finally, the perceived quality dimensions were adopted by following Garvin (1984) and empirical applications by Yoo and Donthu (2002) and Boo, Busser, and Baloglu (2009). Data were analyzed by using Partial Least Square Structural Equation Modeling (PLS-SEM) method and SmartPLS 3.0 software. Specifically, the dimensions used in this study are denoted in the table 1. 
INDEPENDENT JOURNAL OF MANAGEMENT \& PRODUCTION (IJM\&P)

http://www.ijmp.jor.br

v. 11, n. 1, January-February 2020

ISSN: 2236-269X

DOI: 10.14807/ijmp.v11i1.981

Table 1: Variables' dimension used in the study

\begin{tabular}{|c|c|c|}
\hline Latent variables & Labels & Manifest variables \\
\hline \multirow{5}{*}{$\begin{array}{l}\text { Brand awareness } \\
\text { (MacInnis, Shapiro, and } \\
\text { Mani (1999), Keller } \\
\text { (2008), Boo, Busser, and } \\
\text { Baloglu (2009) and Buil, } \\
\text { Martínez, and De } \\
\text { Chernatony (2013) }\end{array}$} & $\mathrm{X} 1$ & The Richeese Factory food packaging is very interesting \\
\hline & $\mathrm{X} 2$ & I know the meaning behind the name of Richeese Factory \\
\hline & $\mathrm{X} 3$ & I know exactly what Richeese Factory sells \\
\hline & $\mathrm{X} 4$ & $\begin{array}{l}\text { Whenever I think of spicy chickens with cheese sauce, I immediately } \\
\text { think of Richeese Factory }\end{array}$ \\
\hline & X5 & I know the logos, colors and other attributes of the Richeese Factory \\
\hline \multirow{3}{*}{$\begin{array}{l}\text { Brand associations } \\
\text { Aaker (1997), Low and } \\
\text { Lamb Jr. (2000), Aaker } \\
\text { (2012) }\end{array}$} & $\mathrm{X} 6$ & $\begin{array}{l}\text { I feel prestigious when eating and making purchases at Richeese } \\
\text { Factory }\end{array}$ \\
\hline & $\mathrm{X} 7$ & $\begin{array}{l}\text { I really like the unique concept of Richeese Factory that offers spicy } \\
\text { chicken products with cheese sauce }\end{array}$ \\
\hline & $\mathrm{X} 8$ & $\begin{array}{l}\text { I believe that Richeese Factory always provides high quality products } \\
\text { at reasonable prices }\end{array}$ \\
\hline \multirow{4}{*}{$\begin{array}{l}\text { Perceived quality } \\
\text { Garvin (1984), Yoo and } \\
\text { Donthu (2002), Boo, } \\
\text { Busser, and Baloglu } \\
\text { (2009) }\end{array}$} & $\mathrm{X} 9$ & Richeese Factory has a strong identity \\
\hline & $\mathrm{X} 10$ & Richeese Factory services a \\
\hline & $\mathrm{X} 11$ & Richeese Factory $\mathrm{F}$ \\
\hline & $\mathrm{X} 12$ & $\begin{array}{l}\text { Free internet service from Richeese Factory has become another } \\
\text { reason for me in buying their products }\end{array}$ \\
\hline \multirow{4}{*}{$\begin{array}{l}\text { Brand loyalty } \\
\text { Foroudi, Jin, Gupta, } \\
\text { Foroudi, and Kitchen } \\
\text { (2018) }\end{array}$} & $\mathrm{X} 13$ & $\begin{array}{l}\text { There are no other fast food brands that offer spicy chickens with } \\
\text { cheese sauce }\end{array}$ \\
\hline & $\mathrm{X} 14$ & I will not be affected by any negative issues about Richeese Factory \\
\hline & X15 & $\begin{array}{l}\text { I am satisfied with Richeese Factory products in terms of how the } \\
\text { products served, the level of spiciness, and the taste of the cheese } \\
\text { sauce }\end{array}$ \\
\hline & $\mathrm{X} 16$ & $\begin{array}{l}\text { I do not mind to buy products at the Richeese Factory with any price } \\
\text { offered }\end{array}$ \\
\hline \multirow{4}{*}{$\begin{array}{l}\text { Brand purchasing } \\
\text { intention } \\
\text { Foroudi, Jin, Gupta, } \\
\text { Foroudi, and Kitchen } \\
\text { (2018) }\end{array}$} & $\mathrm{X} 17$ & I like to eat any product of Richeese Factory \\
\hline & $\mathrm{X} 18$ & I definitely eat Richeese Factory products once in a week \\
\hline & X19 & $\begin{array}{l}\text { I have heard that there is a new Richeese Factory near my university, } \\
\text { and I would love to try and buy its products because of the easily } \\
\text { accessible location }\end{array}$ \\
\hline & $\mathrm{X} 20$ & I will buy the latest products issued by Richeese Factory immediately \\
\hline
\end{tabular}

\section{FINDINGS}

\subsection{Reflective measurement models}

Evaluations on convergent and discriminant validity were performed to evaluate reflective models. Convergent validity consists of item reliability and internal consistency evaluation. The models will have a fairly reliability and construct internal consistency when all the loading factors have values above 0.50 , cronbach's alpha, composite reliability above 0.70 and Average Variance Extracted (AVE) values above 0.50 (COHEN, 1988; HAIR JR. et al., 2016). Furthermore, the evaluation of discriminant validity was carried out by looking at Fornell-Larcker Criterion results. The square root of AVE should be higher than the correlation between constructs (HAIR JR. et al., 2016). 
INDEPENDENT JOURNAL OF MANAGEMENT \& PRODUCTION (IJM\&P)

http://www.ijmp.jor.br

v. 11, n. 1, January-February 2020

ISSN: 2236-269X

DOI: 10.14807/ijmp.v11i1.981

Table 2: Validity and reliability testing results

\begin{tabular}{|c|c|c|c|c|c|c|}
\hline $\begin{array}{c}\text { Latent } \\
\text { constructs }\end{array}$ & Dimensions & $\begin{array}{c}\text { Std. } \\
\text { Loadings }\end{array}$ & t-Statistics & $\begin{array}{c}\text { Average } \\
\text { Variance } \\
\text { Extracted } \\
\text { (AVE) }\end{array}$ & $\begin{array}{l}\text { Composite } \\
\text { reliability }\end{array}$ & $\begin{array}{c}\text { Cronbach's } \\
\text { Alpha }\end{array}$ \\
\hline \multirow{5}{*}{$\begin{array}{l}\text { Brand } \\
\text { awareness }\end{array}$} & $\mathrm{X} 1$ & 0.686 & 14.786 & \multirow{5}{*}{0.552} & \multirow{5}{*}{0.860} & \multirow{5}{*}{0.795} \\
\hline & $\mathrm{X} 2$ & 0.738 & 13.514 & & & \\
\hline & X3 & 0.754 & 12.937 & & & \\
\hline & $\mathrm{X} 4$ & 0.843 & 26.049 & & & \\
\hline & X5 & 0.682 & 11.170 & & & \\
\hline \multirow{3}{*}{$\begin{array}{l}\text { Brand } \\
\text { association }\end{array}$} & X6 & 0.793 & 16.285 & \multirow{3}{*}{0.656} & \multirow{3}{*}{0.851} & \multirow{3}{*}{0.740} \\
\hline & $\mathrm{X} 7$ & 0.828 & 26.970 & & & \\
\hline & X8 & 0.810 & 22.579 & & & \\
\hline \multirow{4}{*}{$\begin{array}{l}\text { Perceived } \\
\text { quality }\end{array}$} & X9 & 0.797 & 19.271 & \multirow{4}{*}{0.563} & \multirow{4}{*}{0.837} & \multirow{4}{*}{0.749} \\
\hline & $\mathrm{X} 10$ & 0.804 & 22.946 & & & \\
\hline & X11 & 0.712 & 9.696 & & & \\
\hline & $\mathrm{X} 12$ & 0.679 & 7.755 & & & \\
\hline \multirow{4}{*}{ Brand loyalty } & $\mathrm{X} 13$ & 0.758 & 13.725 & \multirow{4}{*}{0.582} & \multirow{4}{*}{0.846} & \multirow{4}{*}{0.757} \\
\hline & X14 & 0.638 & 9.835 & & & \\
\hline & X15 & 0.781 & 12.986 & & & \\
\hline & $\mathrm{X} 16$ & 0.858 & 29.338 & & & \\
\hline \multirow{4}{*}{$\begin{array}{l}\text { Brand } \\
\text { purchasing } \\
\text { intention }\end{array}$} & $\mathrm{X} 17$ & 0.608 & 6.496 & \multirow{4}{*}{0.510} & \multirow{4}{*}{0.805} & \multirow{4}{*}{0.687} \\
\hline & $\mathrm{X} 18$ & 0.689 & 8.887 & & & \\
\hline & $\mathrm{X} 19$ & 0.811 & 17.688 & & & \\
\hline & X20 & 0.733 & 12.350 & & & \\
\hline
\end{tabular}

Source: own data processing

The findings in the table 2 and table 3 indicate that all construct dimensions have loading factors above 0.60 . Similarly, AVE values are above 0.50, composite reliability and Cronbach's Alpha are above 0.70 except for the brand purchasing intention which has a value of 0.687 . However, this value is considered moderately acceptable. Fornell larcker criterion results indicate that the AVE root values of all constructs are higher than construct correlations with other constructs. Therefore, it is summarized that the model has good convergent and discriminant validity.

Table 3: Results of Fornell-Larcker criterion

\begin{tabular}{|l|l|l|l|l|l|}
\hline & $\begin{array}{l}\text { Brand } \\
\text { association }\end{array}$ & $\begin{array}{l}\text { Brand } \\
\text { awareness }\end{array}$ & $\begin{array}{l}\text { Brand } \\
\text { loyalty }\end{array}$ & $\begin{array}{l}\text { Brand } \\
\text { purchasing } \\
\text { intention }\end{array}$ & $\begin{array}{l}\text { Perceived } \\
\text { quality }\end{array}$ \\
\hline Brand association & 0.810 & & & & \\
\hline Brand awareness & 0.561 & 0.743 & & & \\
\hline Brand loyalty & 0.722 & 0.758 & 0.763 & & \\
\hline $\begin{array}{l}\text { Brand purchasing } \\
\text { intention }\end{array}$ & 0.664 & 0.600 & 0.625 & 0.714 & \\
\hline Perceived quality & 0.594 & 0.577 & 0.697 & 0.617 & 0.750 \\
\hline
\end{tabular}

Source: own processing data

\subsection{Structural model}

The evaluation of the structural model is performed by looking at t-values and p-values of each hypothesized path, $\mathrm{R}^{2}$ value, and Stone-Geisser's $\mathrm{Q}^{2}$ value. The findings in the table 4 indicate that the relationship between brand awareness and brand loyalty is positive and 
INDEPENDENT JOURNAL OF MANAGEMENT \& PRODUCTION (IJM\&P)

http://www.ijmp.jor.br

v. 11, n. 1, January-February 2020

ISSN: 2236-269X

DOI: 10.14807/ijmp.v11i1.981

significant $(\beta=0.423$; $\mathrm{t}$-value $=6.307)$ providing a support to the hypothesis $1 \mathrm{a}$. Likewise, brand awareness and brand purchasing intention relationships are also positive and significant $(\beta=$ 0.254 ; t-value $=3.233$ ) providing a support to the hypothesis $1 \mathrm{~b}$.

Furthermore, brand association has a positive and significant relationship to brand loyalty $(\beta=0.333$; $\mathrm{t}$-value $=5.420)$ and brand purchasing intention $(\beta=0.388$; $\mathrm{t}$-value $=4.061)$ providing a support to the hypotheses $2 \mathrm{a}$ and $2 \mathrm{~b}$. Similarly, perceived quality has a positive and significant relationship to brand loyalty $(\beta=0.255$; t-value $=3.435)$ and brand purchasing intention $(\beta=0.259$; t-value $=2.714)$. However, brand loyalty does not significantly affect brand purchasing intention $(\beta=-0.027$; t-value $=0.175)$ thus the hypothesis 4 is unsupported. The value of $\mathrm{R}^{2}$ is 0.552 .

According to Hair Jr, Hult, Ringle, and Sarstedt (2016), this value reflects that the model has a good predictive power. The value of $\mathrm{Q}^{2}$ is 0.884 indicating that the model has an excellent predictive power.

Table 4: Path coefficients

\begin{tabular}{|c|l|l|l|l|l|}
\hline Hypotheses & \multicolumn{1}{|c|}{ Path } & \multicolumn{1}{|c|}{ Coeff. } & t-value & \multicolumn{1}{c|}{ p-value } & Decisions \\
\hline H1a & $\begin{array}{l}\text { Brand awareness -> Brand } \\
\text { loyalty }\end{array}$ & $0.423^{* * *}$ & 6.307 & 0.000 & supported \\
\hline H1b & $\begin{array}{l}\text { Brand awareness -> Brand } \\
\text { purchasing intention }\end{array}$ & $0.254^{* *}$ & 3.233 & 0.001 & supported \\
\hline H2a & $\begin{array}{l}\text { Brand association -> Brand } \\
\text { loyalty }\end{array}$ & $0.333^{* * *}$ & 5.420 & 0.000 & supported \\
\hline H2b & $\begin{array}{l}\text { Brand association -> Brand } \\
\text { purchasing intention }\end{array}$ & $0.388^{* * *}$ & 4.061 & 0.000 & supported \\
\hline H3a & $\begin{array}{l}\text { Perceived quality -> Brand } \\
\text { loyalty }\end{array}$ & $0.255^{* *}$ & 3.435 & 0.001 & supported \\
\hline H3b & $\begin{array}{l}\text { Perceived quality -> Brand } \\
\text { purchasing intention }\end{array}$ & $0.259^{* *}$ & 2.714 & 0.007 & supported \\
\hline H4 & $\begin{array}{l}\text { Brand loyalty -> Brand } \\
\text { purchasing intention }\end{array}$ & $-0.027 n . s$ & 0.175 & 0.861 & unsupported \\
\hline
\end{tabular}

Source: own processing data

Notes: n.s=non-significant effects, ${ }^{* * *} \mathrm{p}<0.01 ;{ }^{*} \mathrm{p}<0.05 ;{ }^{*} \mathrm{p}<0.10$

The relationship between each variable and its values is denoted in the figure 2 . 


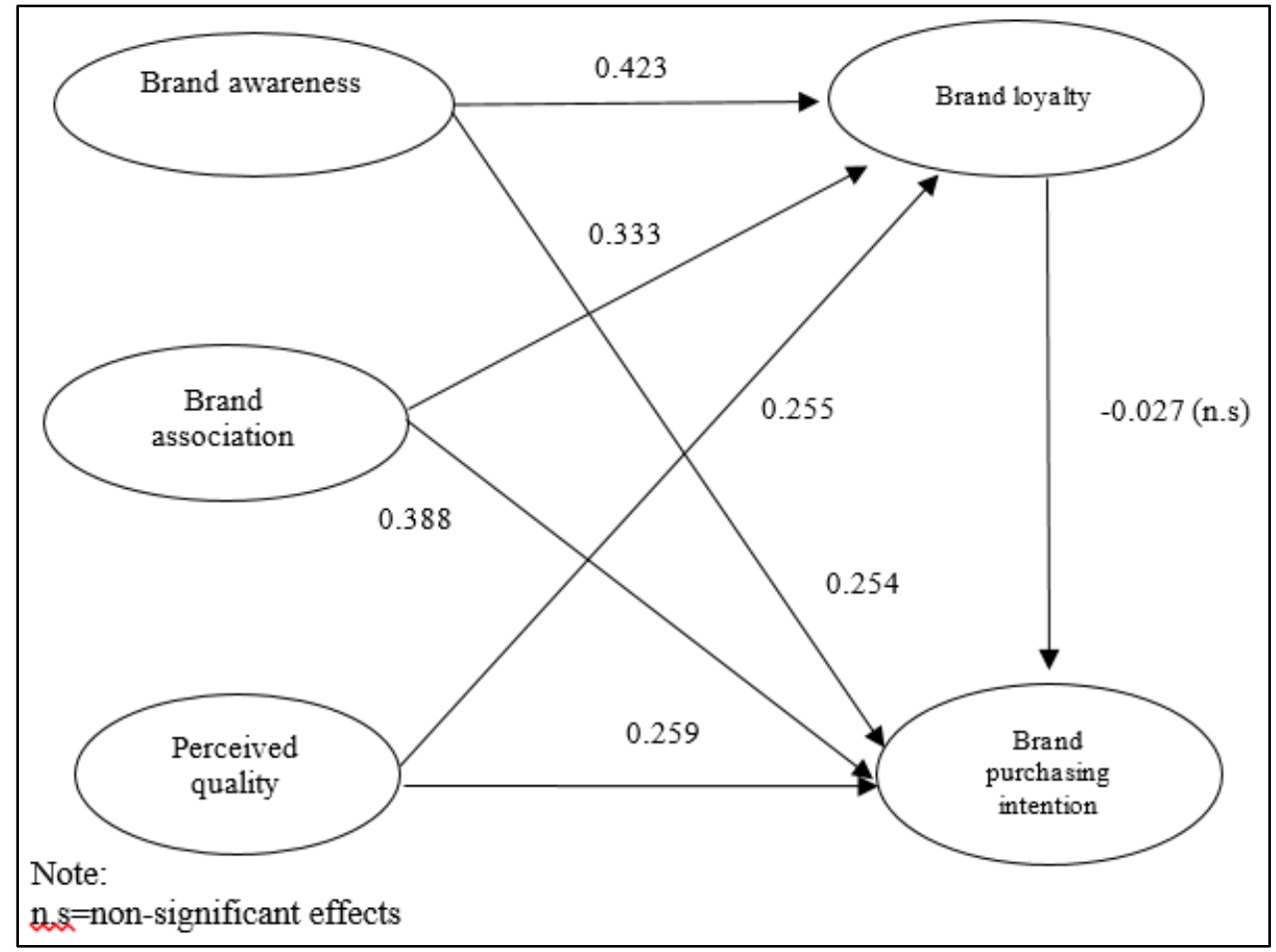

Figure 2: Structural result model of PLS-SEM

In addition, the value of the Goodness of Fit $(\mathrm{GoF})$ index of 0.562 indicates a very good fit model. This is according to the criteria proposed by Wetzels, Odekerken-Schröder, and Van Oppen (2009), where GoF model is divided into three levels, i. e. low GoF (0.100), medium GoF (0.250), and high GoF (0.360). Brand awareness is found to have a positive relationship to brand loyalty and brand purchasing intention. Brand awareness is consumer awareness of the brand existence (SPRY; PAPPU; BETTINA CORNWELL, 2011).

This finding is consistent with Foroudi, Jin, Gupta, Foroudi, and Kitchen (2018), Kim, Choe, and Petrick (2018), and Coelho, Rita, and Santos (2018). The finding indicates that Richeese Factory is well known in the mind of respondents. The higher consumer satisfaction with products and services, the higher their desire to make purchases, repurchases, and affect other people to make the similar purchase.

Furthermore, brand association also has a positive relationship to brand loyalty and brand purchasing intention. This result is consistent with Foroudi, Jin, Gupta, Foroudi, and Kitchen (2018). Consumers are not only able to identify Richeese factory as one of the local fast food brands, but consumers also have been able to identify the product offered, its uniqueness compared to other brands, its innovation, and other form of services (MOHD YASIN; NASSER NOOR; MOHAMAD, 2007). 
INDEPENDENT JOURNAL OF MANAGEMENT \& PRODUCTION (IJM\&P)

http://www.ijmp.jor.br

v. 11, n. 1, January-February 2020

ISSN: 2236-269X

DOI: $10.14807 /$ ijmp.v11i1.981

Likewise, the perceived quality of brand loyalty and brand purchasing intention is positive and significant. This result is consistent with the study of Bao, Bao, and Sheng (2011), Calvo-Porral and Lévy-Mangin (2017), and Foroudi, Jin, Gupta, Foroudi, and Kitchen (2018). Richeese factory's high quality of service that exceeds customer expectations will increase brand loyalty and brand purchasing intention. Service quality covers the product characteristics, services, and wifi availability.

However, brand loyalty does not significantly affect brand purchasing intention. The finding is inconsistent with the study of Tu, Wang, and Chang (2012) and Han et. al. (2018). This is interesting since according to prior studies, brand loyalty should be able to influence consumer attitude and behavior. Attitude means the level of customer satisfaction with Richeese factory. High satisfaction should lead to product purchases. However, in this study we assume that consumers who are satisfied with Richeese factory products and services do not always end up making purchases. This may be affected by other variables such as prices that have not been included in the research model.

\section{CONCLUSION}

This study contributes in analyzing the factors that affect brand equity and brand purchasing intention of a local fast food brand in Jakarta, Indonesia. The finding indicates that there is a positive relationship between brand equity (brand awareness, brand association, perceived quality, and brand loyalty) and brand purchasing intention.

However, the relationship between brand loyalty and brand purchasing intention is not significant. Since the fast food industry has grown very rapidly in Indonesia, high competition must be addressed well by managers by building strong brand equity. The study suggests several managerial implications for local fast food brands.

First, creating strong brand equity will lead to brand loyalty. However, the fact that brand loyalty is not significant in creating brand purchasing intention suggests that managers must pay attention to other factors that may influence consumers to make purchases.

Second, positive effects of brand awareness, brand association, and perceived quality towards brand purchasing intention give a signal for managers to implement specific strategies that can increase the three elements of brand equity, especially on consumers' brand awareness, such as communicating the Richeese Factory name and logo, product variations, improving the packaging to be more attractive and creating a unique way on how the products served to its consumers. 
DOI: 10.14807/ijmp.v11i1.981

\section{REFERENCES}

AAKER, J. L. (1997) Dimensions of brand personality. Journal of marketing research, p. 347-356.

AAKER, D. A. (2009) Managing brand equity. USA: Simon and Schuster.

AAKER, D. A. (2012) Building strong brands. Simon and Schuster.

BAKER, D. A.; CROMPTON, J. L. (2000) Quality, satisfaction and behavioral intentions. Annals of tourism research, v. 27, n. 3, p. 785-804.

BAO, Y.; BAO, Y.; SHENG, S. (2011) Motivating purchase of private brands: Effects of store image, product signatureness, and quality variation. Journal of Business Research, $v$. 64, n. 2, p. 220-226.

BOO, S.; BUSSER, J.; BALOGLU, S. (2009) A model of customer-based brand equity and its application to multiple destinations. Tourism Management, v. 30, n. 2, p. 219-231.

BRUCKS, M.; ZEITHAML, V. A. (1987) Price as an indicator of quality dimensions. In: Association For Consumer Research Annual Meeting, Boston.

BUIL, I., MARTÍNEZ, E.; DE CHERNATONY, L. (2013) The influence of brand equity on consumer responses. Journal of consumer marketing, v. 30, n. 1, p. 62-74.

CALVO-PORRAL, C.; LÉVY-MANGIN, J. P. (2017) Store brands’ purchase intention: Examining the role of perceived quality. European Research on Management and Business Economics, v. 23, n. 2, p. 90-95.

CHENG-HSUI CHEN, A. (2001) Using free association to examine the relationship between the characteristics of brand associations and brand equity. Journal of product \& brand management, v. 10, n. 7, p. 439-451.

COELHO, P. S.; RITA, P.; SANTOS, Z. R. (2018) On the relationship between consumerbrand identification, brand community, and brand loyalty. Journal of Retailing and Consumer Services, v. 43, p. 101-110.

COHEN, J. (1988) Statistical power analysis for the behavioral sciences. 2nd.

FOURNIER, S.; YAO, J. L. (1997) Reviving brand loyalty: A reconceptualization within the framework of consumer-brand relationships. International Journal of research in Marketing, v. 14, n. 5, p. 451-472.

FOROUDI, P.; JIN, Z.; GUPTA, S.; FOROUDI, M. M.; KITCHEN, P. J. (2018) Perceptional components of brand equity: Configuring the Symmetrical and Asymmetrical Paths to brand loyalty and brand purchase intention. Journal of Business Research.

GARVIN, D. A. (1984) What does product quality really mean?. Sloan Management Review, p. 25-43.

GREWAL, D.; KRISHNAN, R.; BAKER, J.; BORIN, N. (1998) The effect of store name, brand name and price discounts on consumers' evaluations and purchase intentions. Journal of retailing, v. 74, n. 3, p. 331-352.

HAIR JR, J. F.; HULT, G. T. M.; RINGLE, C.; SARSTEDT, M. (2016) A primer on partial least squares structural equation modeling (PLS-SEM). Sage Publications.

HAN, H.; NGUYEN, H. N.; SONG, H.; CHUA, B. L.; LEE, S.; KIM, W. (2018) Drivers of brand loyalty in the chain coffee shop industry. International Journal of Hospitality

Management, v. 72, p. 86-97. 
DOI: 10.14807/ijmp.v11i1.981

HANAYSHA, J. (2016). Examining the link between word of mouth and brand equity: A study on international fast food restaurants in Malaysia. Journal of Asian Business Strategy, v. 6, n. 3, p. 41.

HARRINGTON, R. J.; OTTENBACHER, M. C.; FAUSER, S. (2017) QSR brand value: Marketing mix dimensions among McDonald's, KFC, Burger King, Subway and Starbucks. International Journal of Contemporary Hospitality Management, v. 29, n. 1, p. 551-570.

HOMBURG, C.; KLARMANN, M.; SCHMITT, J. (2010) Brand awareness in business markets: When is it related to firm performance? International Journal of Research in Marketing, v. 27, n. 3, p. 201-212.

JALILVAND, M. R.; POOL, J. K.; NASROLAHI VOSTA, S.; KAZEMI, R. V. (2016). Antecedents and consequence of consumers' attitude towards brand preference: Evidence from the restaurant industry. Anatolia, v. 27, n. 2, p. 167-176.

KASHIF, M., AWANG, Z., WALSH, J., \& ALTAF, U. (2015). I'm loving it but hating US: understanding consumer emotions and perceived service quality of US fast food brands. British Food Journal, v. 117, n. 9, p. 2344-2360.

KELLER, K. L.; AAKER, D. A. (1997) Managing the corporate brand: the effects of corporate marketing activity on consumer evaluations of brand extensions. na.

KELLER, J. M. (2008) First principles of motivation to learn and e3-learning. Distance education, v. 29, n. 2, p. 175-185.

KELLER, K. L.; PARAMESWARAN, M. G.; JACOB, I. (2011) Strategic brand management: Building, measuring, and managing brand equity. Pearson Education India.

KIM, S. S.; CHOE, J. Y. J.; PETRICK, J. F. (2018) The effect of celebrity on brand awareness, perceived quality, brand image, brand loyalty, and destination attachment to a literary festival. Journal of Destination Marketing \& Management.

LOW, G. S.; LAMB JR, C. W. (2000) The measurement and dimensionality of brand associations. Journal of Product \& Brand Management, v. 9, n. 6, p. 350-370.

LU, A. C. C.; GURSOY, D.; LU, C. Y. (2015) Authenticity perceptions, brand equity and brand choice intention: The case of ethnic restaurants. International Journal of Hospitality Management, v. 50, p. 36-45.

MAJID, M. A. A.; ALIAS, M. A. M.; SAMSUDIN, A.; CHIK, C. T. (2016) Assessing customer-based brand equity ratings in family restaurant. Procedia Economics and Finance, v. 37, p. 183-189.

MACINNIS, D. J.; SHAPIRO, S.; MANI, G. (1999) Enhancing brand awareness through brand symbols. ACR North American Advances.

MADERER, D.; HOLTBRUEGGE, D.; WOODLAND, R. (2016) The impact of brand associations on brand loyalty in the football industry: A comparison of fans from developed and emerging football markets. Sport, Business and Management: An International Journal, v. 6, n. 5, p. 499-519.

MOHD YASIN, N.; NASSER NOOR, M.; MOHAMAD, O. (2007) Does image of countryof-origin matter to brand equity? Journal of Product \& brand management, v. 16, n. 1, p. 38-48.

PARASURAMAN, A.; ZEITHAML, V. A.; BERRY, L. L. (1985). A conceptual model of service quality and its implications for future research. The Journal of Marketing, p. 41-50. 
PHUNG, M. T.; LY, P. T. M.; NGUYEN, T. T. (2019) The effect of authenticity perceptions and brand equity on brand choice intention. Journal of Business Research.

RACHMAWATI, O. (2018) Franchise Richeese Factory [Internet] [Downloaded on 28 July 2018]. Available at: https://bisniswaralaba.id/franchise-richeese-factory/

ROBINSON, R. N.; CLIFFORD, C. (2012) Authenticity and festival foodservice experiences. Annals of Tourism Research, v. 39, n. 2, p. 571-600.

ROMANIUK, J.; NENYCZ-THIEL, M. (2013) Behavioral brand loyalty and consumer brand associations. Journal of Business Research, v. 66, n. 1, p. 67-72.

SEVERI, E.; LING, K. C. (2013) The mediating effects of brand association, brand loyalty, brand image and perceived quality on brand equity. Asian Social Science, v. 9, n. 3, p. 125.

SINGH, P. K.; PATTANAYAK, J. K. (2016) Study of the relationship among the factors of brand equity: A study on fast-food brands. Global Business Review, v. 17, n. 5, p. 1227 1239.

SNOJ, B.; PISNIK KORDA, A.; MUMEL, D. (2004) The relationships among perceived quality, perceived risk and perceived product value. Journal of Product \& Brand Management, v. 13, n. 3, p. 156-167.

SPRY, A.; PAPPU, R.; BETTINA CORNWELL, T. (2011) Celebrity endorsement, brand credibility and brand equity. European Journal of Marketing, v. 45, n. 6, p. 882-909.

SUN, L.; GHISELLI, R. F. (2010) Developing a conceptual model of brand equity in the hotel industry based on Aaker's perspective. Journal of Quality Assurance in Hospitality \& Tourism, v. 11, n. 3, p. 147-161.

TAN, T. M.; DEVINAGA, R.; HISHAMUDDIN, I. (2013) The common challenges of brand equity creation among local fast food brands in Malaysia. International Journal of Business and Management, v. 8, n. 2, p. 96.

TANTIA, D. R. (2017). Pengaruh kualitas pelayanan, harga, promosi dan kualitas produk terhadap keputusan pembelian pada makanan cepat saji KFC coffee. [Bachelor Thesis]. Lampung: University of Lampung.

TSAI, C. T. S.; LU, P. H. (2012) Authentic dining experiences in ethnic theme restaurants. International Journal of Hospitality Management, v. 31, n. 1, p. 304-306.

TU, Y. T.; WANG, C. M.; CHANG, H. C. (2012) Corporate brand image and customer satisfaction on loyalty: An empirical study of Starbucks coffee in Taiwan. Journal of Social and Development Sciences, v. 3, n. 1, p. 24-32.

WETZELS, M.; ODEKERKEN-SCHRÖDER, G.; VAN OPPEN, C. (2009) Using PLS path modeling for assessing hierarchical construct models: Guidelines and empirical

illustration. MIS quarterly, p. 177-195.

YOO, B.; DONTHU, N. (2002) Testing cross-cultural invariance of the brand equity creation process. Journal of Product \& Brand Management, v. 11, n. 6, p. 380-398.

ZEITHAML, V. A. (1988) Consumer perceptions of price, quality, and value: a means-end model and synthesis of evidence. The Journal of marketing, p. 2-22.

ZHANG, S. S.; VAN DOORN, J.; LEEFLANG, P. S. (2014) Does the importance of value, brand and relationship equity for customer loyalty differ between Eastern and Western cultures? International business review, v. 23, n. 1, p. 284-292. 